\title{
Madde Bağımlılığı Ve Benlik Saygısı Arasındaki İlişki Konusunda Yapılan Çalışmalar Üzerine Bir İnceleme
}

\author{
Taner EROL ${ }^{1}$
}

\begin{abstract}
Özet: Literatürde, madde bağımlılığının kişinin benlik saygısını etkilediği görülmüştür. Madde bağımlılığının gerek maddi nedenler gerekse manevi duygulara bağlı olarak gelişebileceği ve insan hayatı üzerinde önemli etkiler bırakabileceği araştırmalar sonucunda ortaya çıkmıştır. Madde bağımlılığıyla benlik saygısı arasında bir ilişki olduğu ve bu ilişkinin incelenmesinin benlik saygısı düzeyini ortaya koyması açısından önem arz edeceği düşünülmüştür. Bu çalışmada beş yıl içerisinde Yüksek Öğretim Kurumu Tez Dokümantasyon Merkezine kayıtlı ve elektronik ortamda ulaşılabilen, izinli, dili Türkçe, 2014-2019 yılları arasındaki lisansüstü tezlerle ve google akademiden bu aralıkta ulaşılan yayımlartaranmıştır. İki kavram arasındaki ilişki konusunda yapılan tespitler bir araya getirilerek bundan sonra konu ile ilgili yapılacak çalışmalara 1şık tutmaya çalışılacaktır.
\end{abstract}

Anahtar kelimeler: Benlik, Benlik Saygısı, Bağımlılık, Madde Bağımlılığı

\section{A Research On Studies Regarding The Relationship Between Substance Abuse And Self-Esteem}

\begin{abstract}
In the literature, it is apparent that substance abuse affects one's self-esteem. It has emerged as a result of research that substance abuse may be developed both from substantial reasons and spiritual feelings, and will have a significant impact on human life. It is estimated that there is a relationship between substance addiction and self-esteem, and examining this relationship will be important in terms of revealing self-esteem level. In this study, in the last five years, the publications which are registered to the The sis Documentation Center of the Higher Education Institution and which can be accessed electronically, with permission, the language is Turkish, between the years 2014-2019 and the publications reached from the google academy were scanned. The findings and the relationship between the two notions will be brought together to shed light on the future studies.
\end{abstract}

Key words: Self, Self-Esteem, Addiction, Substance Addiction

${ }^{1}$ Ögr. Gör. Taner EROL, Recep Tayyip Erdoğan Üniversitesi, Sosyal Bilimler Meslek Yüksekokulu Address of correspondence/Yazışma adresi: Ögr. Gör. Taner EROL, Recep Tayyip Erdoğan Üniversitesi, Sosyal Bilimler Meslek Yüksekokulu, Rize, E-mail: taner.erol@erdogan.edu.tr

Date of Received/ Geliş Tarihi: 27.10.2019, Date of Revision/ Düzeltme Tarihi: 02.11.2019, Date of Acceptance/ Kabul Tarihi: 07.11.2019

Citing/ Referans Gösterimi: Erol, T. (2019). Madde Bağımlılı̆̆ı Ve Benlik Saygısı Arasındaki İlişki Konusunda Yapılan Çalışmalar Üzerine Bir İnceleme. Klbrı Türk Psikiyatri ve Psikoloji Dergisi, 1(Ö̈zel Sayı.1): 56-58 doi:10.35365/ctjpp.19.special1.16 


\section{Giriş}

Literatürde madde kullanan kişilerde benlik saygısının ölçülmesiyle ilgili araştırmaların yetersiz olduğu dikkat çekmiştir. $\mathrm{Bu}$ nedenle bu çalışmadaki amaç; madde bağımlılığı ve benlik saygısının tanımı yapılıp, iki kavram arsındaki ilişki hakkında son beş yılda yapılan çalışmaların derlenerek araştırmaların kapsamı hakkında bilgi vermek, literatüre katkı sağlamak ve madde bağımlılığı, benlik saygısı ilişkisinin literatürde nasıl olduğuyla ilgili perspektif sunacaktır.

Çalışmanın girişinden sonra;çalışmanın yöntemi, verilerin toplanması ve analizi, amacı, sinırlılıkları,grubu, bulguları,bağımlılık, madde bağımlılı̆̆ı, benlik, benlik saygısı kavramları tanımlanacak ve literatür taraması yapılacaktır. Son olarak sonuç ve kaynakçaya yer verilecektir.

\section{Araştırmanın Yöntemi}

Nitel araştırma yöntem, teknikleri kullanılarak yapılandırılmıştır.

\section{Verilerin Toplanması ve Analizi}

Veriler nitel araştırma veri toplama yöntemlerinden doküman incelemesi tekniği kullanılarak toplanmıştır.Ayrıca veriler, Yüksek Öğretim Kurumuna bağlı ulusal tez merkezi sayfasında yapılan taramalar ve google akademiden elde edilen çalışmalar sonucunda toplanmıştır.

\section{Çalışmanın Amacı}

Madde bağımlılığıyla benlik saygısı arasındaki ilişkiyi araştıran çalışmaları tespit edip, çalışmaların bu konu hakkındaki özet görüşüne yer verme amacını taşımaktadır.

\section{Araştırmanın Sınırlılıkları}

$\mathrm{Bu}$ çalışma; Yüksek Öğretim Kurumu Tez Dokümantasyon Merkezine kayıtlı ve elektronik ortamda ulaşılabilen, izinli, dili Türkçe, 2014-2019 yılları arasındaki lisansüstü tezlerle ve google akademikde bu aralıkta ulaşılan yayınlarla sınırlıdır.

\section{Çalışma Grubu}

Araştırmanın çalışma grubunu, 2014-2019 yılları arasında Yüksek Öğretim Kurumu Tez Dokümantasyon Merkezine ve google akademikdekayitlı elektronik ortamda ulaşılabilen on bir lisansüstü tez ve makaleden oluşmaktadır.

\section{Bulgular}

$\mathrm{Bu}$ bölümde, yapılan taramada elde edilen yayınların künyesine yer verilmiştir.

\section{Bağımlılık ve Madde Bağımlılığı}

Bir insana, canlıya, eşyaya karşı hissedilen geri durulmaz duygu vefarklı düşüncenin etkisi altında kalma durumu. Duygusal ve fiziksel sihhatine veya hayatına olumsuz etki etmesine rağmen, bireylerin yaşadığı durumu takıntıya dönüştürmesi, tekraren yaşama duygusunun zirvede olmas1, bu durumu devam ettirmesi olarak da açıklayabiliriz (Uzbay, 2009).

\section{Benlik ve Benlik Saygısı}

Literatüre benlik ikiye ayrılır: akademik olarak tanımlanmayan benlik; toplumsal, duygusal ve şekilsel benlik. Akademik olarak benlik; matematik, fen, yabanc1 dil gibi alanlarla ilişkilendirilir. Şekilsel benliği de şekilsel kabiliyet ve şekilsel görünüm olarak ayırabiliriz (Tözün, 2010).

\section{Literatür Taraması}

Petin (2014),denetimli serbestlik çerçevesinde madde kullananların sağlığına kavuşması için aile desteğinin kişinin iyileşmesine etki derecesi araştırmıştır.

Ölçüm (2014), yapmış olduğu çalışmada, madde kullanan gençlerin benlik saygısı, daha önceki dönemlerde hayatında görmüş olduğu baskı seviyesi ve öfkesini yansıtma şeklinin madde kullanmayan gençlerle kıyaslanması hedeflemiştir.

Aydın (2015), tarafından yapılan çalışmada madde bağımlısı teşhisi konulan, NP psikiyatri hastanesinde ayakta ve yatakta hizmet alan 35 bireyi ve madde bağımlılı̆̆ı söz konusu olmayan 35 bireyi çalışma kitlesi olarak belirlemiştir.

Kasap (2015), 15-17 yaş aralığında olan gençlerde madde bağımlılığıyla ilgili unsurları araştırmıştır.

Bozbey (2015), ülkemizde bağımlılıkla mücadele eden bir merkezde tedavi edilen ve maddenin olumsuz kullanımı ya da madde ile ilgili bağımlılık teşhisi konulan gençlerde oluşan psikolojik problemlerianaliz etmiştir.

Demirci (2016),üniversite öğrencilerinde madde bağımlılı̆̆ gerçekleştirmiştir.

Kaya (2016), madde kullanan, kullanmayan ergenlerin kişilik özellikleri ve benlik saygısı düzeylerinin sosyodemografik değişkenlere göre incelenmesi adlı çalışmayı literatüre kazandırmıştır.

Şahin (2017), madde bağımlılığı tanısı almış kişilerde benlik saygısıyla sosyal fobi arasındaki ilişkinin incelenmesi adlı çalışmasını gerçekleştirmiştir.

Alban (2018), Alkol-Madde Bağımlısı Bireylerde İçselleştirilmiş Damgalama ve Benlik Saygısı; Elazı̆̆ RSHHastanesi Amatem Örneği adlı bir çalışma yapmiştır.

Kulu ve ark. (2018),"Bağımlılıkta Düzenli Egzersizin Benlik Saygısına Etkisi” başlıklı araştırma gerçekleştirmiştir.

Çinka (2019), Madde Bağımlılığının Deri-Benlik Kuramı Çerçevesinde Değerlendirilmesi adlı araştırmayı ortaya koymuştur.

\section{Sonuç ve Tartışma}

Günümüzün en ciddi problemlerinden bir tanesi madde bağımlılığı ve onunla mücadele edebilmektir. Madde bağımlılığının her kişiye bırakacağı etki göreceli bir durumdur. Hesap edilebilir bir hasarın olmaması bu bağımlılığa karşı önceden tedbir almayı gerektirir. Bunun için de insan hayatını hangi konularda etkileyebileceği konusunun iyi irdelenmesi gerekir.

Madde bağımlılığının insan hayatı ile ilgili birçok sonucu vardır ve bunlardan bir tanesi de psikolojiktir. Psikolojik 
noktada da birçok sonuçtan bahsedebiliriz. Bunların en önemli çıktılarından birinin de benlik saygısı olduğunu söyleyebiliriz. Literatürde madde bağımlılığını benlik saygısı ile ilişkilendiren bazı çalışmalar mevcuttur. Fakat psikolojik alana kategorize edebileceğimiz; depresyon, kayg1, intihar gibi problemlerin, benlik saygisından daha fazla çalışılmış olduğu yapılan literatür araştırmasında gözlemlenmiş̧ir. Gerek nitelik gerek nicelik olarak benlik saygısı ile madde bağımlılığı arasındaki ilișkiyi inceleyen çalışmaların eksikliği tespit edilmiş olup yeterli sayıda çalışmanın literatüre kazandırılması gerektiği düşünülmektedir.

Benlik saygısının fizyolojik etkilerinin de olabileceğini bunun yanında psikolojik ve sosyolojik sonuçlarının da azımsanacak derecede olmadığını söyleyebiliriz. Ayrıca iş hayatında da birçok çıktısının olabileceğini düşünürsek yapılan çalışmaların eksik olduğu veya daha detaylı yapılması gerektiğinin tespiti bu çalışmada gözlemlenmiştir.

Benlik saygısının düşük olması veya yüksek olmasının diğer psikolojik problemleri de etkileyeceği yapılan çalıșmalarda anlașılmaktadır. Kelebek etkisiyle bu hastalıklar birbirini etkileyerek içinden çıkılmaz bir hale gelebilir. $\mathrm{Bu}$ bağlamda bütün psikolojik hastalıkları madde bağımlılığına karşı ilişkilendirmek gerekir. Çünkü madde kullanımı bu hastalıkları tetikleyebilir. Ayrıca aynı grupta değerlendirilebilecek olan psikolojik hastalıklar da madde kullanımı ile birlikte birbirine yaklaşıp yeni bir davranışa neden olabilir. Örneğin; madde kullanan benlik saygısı düşük birinin intihar edebilme oranının madde kullanan benlik saygısı yüksek bir kişiye göre daha fazla olup olmayacağını araştırmalar ortaya çıkarmalıdır. Bunun gibi birçok örneğin ilişkisi ve derecesi tespit edilebilirse bu bağımlılığa karșı mücadeleyi de gerçekleştirdiğimiz eğitim müfredatlarına bir bulgu olarak ekleyebiliriz. $\mathrm{Bu}$ bulgular madde bağımlılığından önce özellikle ergen dönemde insanlara 1ş1k tutmak için önem arz etmektedir.

Madde bağımlılı̆̆ının bütün dünya için insan hayatını önemli derecede etkileyen bir husus olduğu herkes tarafindan kabul edilen bir sonuçtur. Dolayısı ile madde bağımlılığının etki edebileceği bütün psikolojik unsurların detaylı bir şekilde araştırılması gerekmektedir. $\mathrm{Bu}$ araştırmalar yüzeysel kaldığı sürece madde bağımlılığıyla mücadelede bir ayak eksik kalacaktır.

Sonuç olarak yapılan çalışma, madde bağımlılığıyla benlik saygısının arasındaki ilişkiyi araştıran literatür çalışmalarını tespit edip, çalışmaların bu konu hakkındaki özet görüşünün neler olduğuna yer vermek amacını taşımaktadır. Ayrıca tespit edilen çalışmaların nitelik ve nicelik yönünden yeterli olup olmadığ değerlendirilmiştir. Son beş yılda yapılan çalıșmalara yer verilen bu araştırmada madde bağımlılığının birçok psikolojik faktörle ilişkilendirildiği ama benlik saygısı ile ilgili yeteri kadar araştırmanın yapılmadığ edilmiștir. Yapılan çalıșmada madde bağımlılı̆̆ benlik saygısının akademik anlamda çalışılıp literatüre katk1 sağlanılması gerektiğinin altı çizilmektedir. Araştırmacılara yapılması gereken çalışmalar hakkında 1ş1k tutmak hedeflenmiştir. Bu vesileyle literatürde bu konu ile ilgili bir eksikliğin olduğu tespit edilmiş oldu. Özellikle madde bağımlılığının benlik saygısı ile ilișkisinin ne olduğuyla ilgili çalışmalar yapılacak olursa; gerek madde kullananların düşük ve yüksek benlik saygısı düzeyleri olan kişilere nasıl etki edeceği tespit edilirken gerekse benlik saygısı düşük veya yüksek olan kişilerde madde kullanımına karşı düşünce ve tutum şekli önceden tespit edilmiş olacaktır.

\section{Kaynaklar}

Alban, K. (2018),Alkol-Madde Bağımlısı Bireylerde İçselleștirilmiș Damgalama Ve Benlik Saygısı; Elazığ RSH Hastanesi Amatem Örneği, Y.L. Tezi, Fırat Üniversitesi, Elazı̆̆

Aydın, Y.(2015),Alkol Ve Madde Bağımlılığında Beden Algısı, Benlik Saygısı Düzeyleri Ve Sosyal Fobi Görülme Sıklığı: Karşılaştırmalı Bir Çalışma, Y.L Tezi, Üsküdar Üniversitesi, İstanbul

Bozbey, S.(2015),Madde Kötüye Kullanımı veya Madde Bağımlılı̆ı Tanısı Alan Çocuk ve Ergenlere Eşlik Eden Psikiyatrik Bozuklukların İncelenmesi, Tıpta Uzmanlık Tezi, Bakırköy Prof. Dr. Mazhar Osman Ruh Sağlığı Sinir Has. Eğt. Arș. Hastanesi, İstanbul

Cinka, E.(2019),Madde Bağımlılığının Deri-Benlik Kuramı Çerçevesinde Değerlendirilmesi, Y.L Tezi, İstanbul Üniversitesi, İstanbul

Demirci, M.(2016),Üniversite Öğrencilerinde Madde Bağımlılı̆̆ı, İntihar İlişkisi, Y.L Tezi, İstanbul Aydın Üniversitesi, İstanbul

Kasap, Hülya (2015),15-17 Yaş Grubu Ergenlerde Sosyal Destek, Okul Başarısı, Aile Yapısının Madde Bağımlılı̆̆ına Karşı Koruyucu Etkisi, Yüksek Lisans Tezi,
Kaya, Z.(2016),Madde Kullanan Ve Kullanmayan Ergenlerin Kişilik Özellikleri, Benlik Saygısı Düzeylerinin Sosyodemografik Değiş̧enlere Göre İncelenmesi, Journal of Human Sciences, Volume:13 Issue:3:2016

Kulu M,Özsöy F, Baykara S (2018), Bağımlılıkta düzenli egzersizin benlik saygisına etkisi. Anadolu Psikiyatri Dergisi,19(3),244-249.

Ölçüm, H.İ.(2014),Madde kullanımı olan ve olmayan ergenlerin benlik saygısı, çocukluk örselenme yaşantıları, öfke ifade biçimleri yönünden karșılaştırılması, Y.L Tezi, Ege Üniversitesi, İzmir.

Petin, Buket (2014),Denetimli Serbestlik Kapsamında Madde Bağımlılığı İçin Tedaviye Yönlendirilen Olguların Algıladıkları Aile Desteğinin Tedaviye Etkisi ve Ailelerinde Psikiyatrik Tanı Varlığı, Tıpta Uzmanlık Tezi, Ege Üniversitesi, İzmir

Sahin, Ö.(2017),Madde Bağımlılı̆̆ı Tanısı Almıș Kișilerde Benlik Saygısıyla Sosyal Fobi Arasındaki İlişkinin İncelenmesi, Y.L,Haliç Üniversitesi, İstanbul

Tözün M.(2010),Benlik saygısı. Actual Medicine,1:52-56.

Uzbay, İ.T.(2009),Madde Bağımlılı̆̆ının Tarihçesi, Tanımı, Genel Bilgiler ve Bağımlılık Yapan Maddeler. Türk Eczacılar Birliği Yayını/Meslek İçi Sürekli Eğitim Dergisi: Sayı:21-22, s:515. 